\title{
Recent Changes to a Measure of U.S. Household Debt Service
}

Karen Dynan, Kathleen Johnson, and Karen Pence, of the Board's Division of Research and Statistics, prepared this article. Dovid Brown provided research assistance.

Changes in aggregate household debt in the United States may contain information about the current state of the economy and may influence its future path. When a large share of household income is devoted to debt repayment, households have fewer funds available to purchase goods and services. Households with high debt levels relative to income are also more likely to default on their obligations when they suffer an unanticipated misfortune such as job loss or illness. Thus, when household debt ratios are high and unemployment is rising, lenders may respond to the expected increase in defaults by limiting the availability of credit; this dynamic may further weigh on spending.

An often-used summary measure of household debt is the household debt service ratio (formerly known as the household debt service burden), which the Board of Governors of the Federal Reserve System first published in 1980. ${ }^{1}$ This measure, which is intended to capture the share of household after-tax income obligated to debt repayment, is calculated as the ratio of aggregate required debt payments (interest and principal) to aggregate after-tax income.

Changes in the structure and sophistication of financial markets in the past several years appear to have affected household debt service ratios. In the residential mortgage market, lenders have developed products that have broadened the base of household debt by enabling borrowers with impaired credit or limited funds for a down payment to purchase homes. Advances in home equity lending have enabled borrowers to extract equity more easily from their homes through a home equity line of credit or a cash-out refinancing. In the auto finance market, more drivers than in the past are leasing their cars instead of

1. See Charles Luckett, "Recent Financial Behavior of Households," Federal Reserve Bulletin, vol. 66 (June 1980), pp. 437-43, for more details. The data for the revised debt service ratio discussed in this article are available at www.federalreserve.gov/releases/ housedebt/default.htm. purchasing them, while in the education finance market, market share has shifted from commercial bank loans to government-financed student loans.

Because of such changes in financial markets, Federal Reserve staff undertook a major revision of the debt service ratio (DSR), which had last been revised in 1999. In the current revision, the staff had three goals. The first was to evaluate and update the data sources and the methods used to calculate the DSR. The second was to create a broader measure of household liabilities, the financial obligations ratio (FOR), which added recurring obligations - rent, auto leases, homeowners' insurance, and property taxes - that had not traditionally been included in the calculation of the DSR. The third goal was to analyze the effect of recent mortgage market changes on the debt of homeowners by creating estimates of the FOR for homeowners and renters. The results of these revisions are presented in this article.

Interpretation of the DSR and these revisions is subject to several caveats. First, the DSR is a ratio of minimum debt payments, not total debt, to income. Required monthly payments can differ on loans of the same dollar amount because of differences in maturities and interest rates. Second, the measure is a ratio of two aggregate numbers. This measure expresses the debt service obligations of the population as a whole but not necessarily the obligations of the typical household. ${ }^{2}$ Third, what the DSR indicates about the economy is not straightforward because it does not incorporate the intentions or expectations of borrowers. Some households may increase their ratios by borrowing more because they are appropriately optimistic about their future income prospects and their corresponding ability to repay debt. Other households may increase their ratios because they have suffered an unanticipated misfortune that necessitates borrowing to cover their extra expenses. An

2. The Survey of Consumer Finances releases an estimate every three years of the median household debt service ratio, which can be interpreted as the debt service ratio of a typical household that has debt. This measure fell from 18.1 percent of income in 1998 to 16.0 percent in 2001. See Ana M. Aizcorbe, Arthur B. Kennickell, and Kevin B. Moore, "Recent Changes in U.S. Family Finances: Evidence from the 1998 and 2001 Survey of Consumer Finances," Federal Reserve Bulletin, vol. 89 (January 2003), pp. 1-32, for more details. 
1. Share of dollars outstanding, by type of nonauto, nonrevolving loans, 1983-2001

Percent

\begin{tabular}{|c|c|c|c|c|c|c|c|c|}
\hline \multirow{2}{*}{ Year } & \multicolumn{2}{|c|}{ Stu.ent } & \multicolumn{2}{|c|}{ Mobile home } & \multicolumn{2}{|c|}{$\mathrm{RV}$ and marine } & \multicolumn{2}{|c|}{ Personal } \\
\hline & Previous & Revised $^{1}$ & Previous & Revised $^{1}$ & Previous & Revised $^{1}$ & Previous & Revised $^{1}$ \\
\hline $1983 / 1985^{2}$ & 30 & 28 & 19 & 24 & 10 & 21 & 40 & 28 \\
\hline & 33 & 38 & 24 & 19 & 23 & 24 & 20 & 20 \\
\hline 1992 & 37 & 51 & 14 & 15 & 29 & 17 & 21 & 17 \\
\hline 1995 & 44 & 55 & 8 & 21 & 22 & 14 & 26 & 11 \\
\hline $1998 \ldots \ldots$ & 17 & 53 & 11 & 21 & 37 & 18 & 36 & 8 \\
\hline $2000 / 2001^{2}$ & 12 & 58 & 6 & 21 & 31 & 14 & 51 & 8 \\
\hline
\end{tabular}

1. These figures are based on loans reported to be from banks, finance companies, credit unions, and stores.

2. Survey of Consumer Finances (SCF) data are available for 1983 and 2001, whereas American Bankers Association (ABA) data are available for 1985 and 2000 .

increase in the DSR indicates good news for the economy in the first example and bad news in the second.

\section{UPDATING SOURCES OF DATA FOR THE. DSR}

Recent developments in credit markets necessitated changing some sources of the data used to calculate the DSR. Commercial banks' changing role in household credit markets led to replacing a bank-level survey with a household-level survey as the source for the distribution of loan types. In the process of revision, members of the Board staff re-evaluated and updated the data sources for loan maturities and interest rates. Also, changes in the student loan market led to using new sources of data for student loans.

\section{Using a New Source of Nonauto, Nonrevolving Debt Shares}

In the calculation of the DSR, aggregate nonauto, nonrevolving debt is split into its component partsstudent loans, mobile-home loans, recreational vehicle (RV) and marine loans, and personal loansbecause these loans have different interest rates and maturities and so have different amounts of debt service associated with a given increase in debt. ${ }^{3}$ In the past, the aggregate was split with shares estimated from the American Bankers Association survey of banks. However, the role of commercial banks in household credit markets has changed, and we

3. Revolving debt arises from retail credit extended on the basis of a credit line and from the sale of services and consumer goods other than passenger cars and mobile homes. A single contract governs multiple use of the account, and purchases may be made with a credit card. Generally, credit extensions can be made at the consumer's discretion, provided that they do not cause the outstanding balance of the account to exceed a prearranged credit limit.

Nonrevolving debt comprises all other loans not included in revolving credit that are unsecured or are secured by collateral other than real estate.
SoURCES. For "previous" column, American Bankers Association Installment Credit Report. For "revised" column, Survey of Consumer Finances, various waves.

have become less confident that banks' distribution of loan types represents the distribution for the credit market as a whole.

One example of the changing role of commercial banks in household credit markets is the student loan market. From 1983 to 2001, student loans as a share of commercial banks' nonauto, nonrevolving loan portfolio-the previous basis for our estimatesdeclined from 30 percent to 12 percent (table 1). Over the same period, student loans as a share of households' nonauto, nonrevolving debt-the revisedbasis for our estimates - increased from about 28 percent to 58 percent. That these shares show opposite trends implies that households are obtaining education loans from lenders other than commercial banks, such as the federal government.

Another example is the market for personal loans. Between 1983 and 2001, personal loans as a share of commercial banks' nonauto, nonrevolving consumer loan portfolio fluctuated in a wide band around 30 percent. At the same time, personal loans were declining as a share of households' nonauto, nonrevolving credit; in 2001, they made up only 8 percent of such credit, down from 28 percent in 1983. One possibility is that personal loans have been replaced by credit card debt, a type of revolving debt that has more than doubled as a share of total consumer debt in the past two decades.

To obtain information about such markets, we turned to the Survey of Consumer Finances (SCF) (see box). This survey gathers detailed information on households' financial characteristics. Part of this information concerns households' outstanding consumer loans from all types of lenders.

\section{Updating Assumptions about the Time to Maturity}

The assumptions about the remaining time to maturity of the loans outstanding (remaining maturity) 
2. Comparison of interest rates on nonauto, nonrevolving credit in the SCF with those currently used in the DSR calculation, 1983-2001

Percent

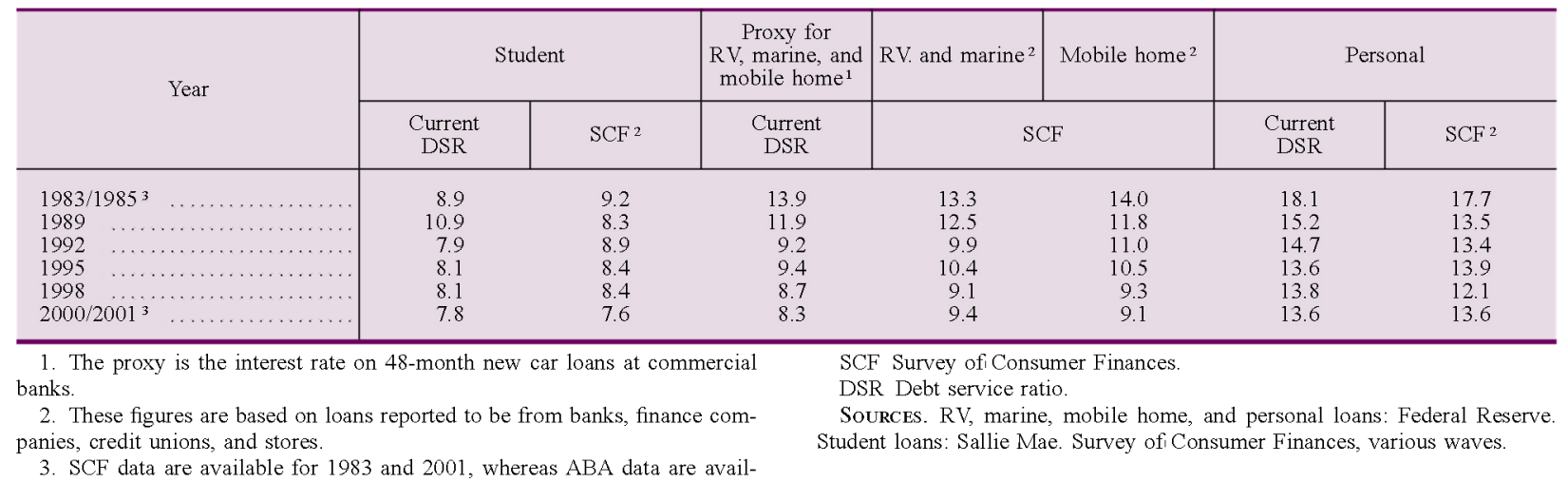

and 2001, whereas ABA data are available for 1985 and 2000 .

used to calculate the DSR have been in place for several years and do not capture the recent changes in credit markets. These maturity assumptions have important implications for the DSR calculation because longer-maturity loans have lower payments, all else being equal, whereas shorter-maturity loans have higher payments. The average remaining times to maturity on types of nonrevolving debt other than auto loans are available infrequently and need to be re-evaluated from time to time.

To update the maturity assumptions, we again turned to the $\mathrm{SCF}^{4}$ For example, after examining the SCF data and consulting with industry contacts, we raised the assumed remaining maturity for mobilehome loans to 100 months. ${ }^{5}$ The SCF data also indicated that the average remaining maturity on personal loans-of 42 months-was much longer than the previously assumed maturity of 16 months, and so we lengthened this maturity assumption as well. Finally, although the SCF's average remaining maturity for student loans currently being paid-at 65 months-is fairly close to our previous assumption of 80 months, payments on a large number of student loans are currently being deferred. According to the $\mathrm{SCF}$, at any given time, payments are not being made on one-quarter to one-half of student loans. To

4. The SCF does not ask households for the remaining maturity on their loans in all cases, but we calculated the implied remaining maturity by subtracting the age of the loan from the original maturity.

5. The remaining maturity on mobile homes was previously assumed to be 40 months; the average remaining maturity captured by the SCF is about 149 months. However, the remaining maturity calculated from the SCF may not accurately represent the remaining maturity on household debt because the SCF measure of mobile-home debt includes mobile homes and sometimes the land on which they stand. The loan for this land would have a substantially longer maturity than would that for the mobile home itself. account for the deferral of student loans, we adjusted the stock of loans to reflect only those loans on which payments are currently being made.

\section{Re-evaluating and Updating the Interest Rate Data}

We have also re-evaluated and updated the sources of data on interest rates. In the past, we used proxies for interest rates on $\mathrm{RV}$, marine, and mobile-home loans. ${ }^{6}$ According to the SCF, however, the interest rates on these loans are similar to each other and to the Federal Reserve's series on the average interest rate offered by banks on 48-month new car loans (see table 2). Thus, we replaced the previously used proxies with this rate, which is 3 to 4 percentage points lower than the proxies we had been using.

As part of the re-evaluation, we compared the quarterly interest rates for student loans from Sallie Mae and those for personal loans from the Federal Reserve with data from the SCF. The student loan interest rate, which is the average interest rate on Stafford student loans as reported by Sallie Mae, is similar to the rate reported in the SCF. Over the past twenty years, each rate has shown only mild fluctuations around its average of 8.5 percent. ${ }^{7}$ Interest rates on personal loans in the SCF, defined as all nonrevolving loans for purposes other than education or the purchase of an RV, a boat, or a mobile home,

6. We previously used the interest rate on used cars at finance companies as a proxy for the interest rate on RV and marine loans, and the interest rate on 48-month new car loans at commercial banks plus a constant as a proxy for the interest rate on mobile-home loans.

7. The similarity is not too surprising - a comparison of student loan rates by source in the SCF reveals little difference across types of lending institution. 
appear to be a bit lower than the rates offered by banks on 24-month personal loans, but this difference has been close to zero in recent years.

\section{Adding New Sources for Student Loan Data}

The DSR was broadened to account for changes in the student loan market. Specifically, the measure of consumer credit used to calculate the DSR was expanded to include student loans extended by the government and Sallie Mae. ${ }^{3}$ From the household sector's perspective, student loans made by the government or Sallie Mae do not differ fundamentally from those made by other lenders. However, these student loans were not captured in the consumer credit statistics because information about student loans had traditionally been collected through surveys of banks."

Before 1993, the federal government participated indirectly in the student loan market by guaranteeing loans made available by private lenders, a good portion of which were commercial banks. ") In 1993, it began disbursing education loans directly to households through the congressionally mandated Federal Direct Student Loan Program (FDSLP). "' The FDSLP expanded rapidly, and by the end of the decade, the program was responsible for one-quarter of the approximately $\$ 177$ billion in student loans outstanding under federal programs. ${ }^{12}$ Accounting for student loans extended by the federal government raised the level of consumer credit an average of 3 percent since 1994 and its annual growth rate about $1 / 2$ percentage point each year.

Sallie Mae's student loans had not been included in the consumer credit statistics because consumer credit information traditionally had not been collected from government-sponsored enterprises. However, loans from Sallie Mae's parent company (SLM),

8. The consumer credit data used in the calculation are published by the Federal Reserve in the G. 19 statistical release. A revision back to January 1977 first appeared in the October 7, 2003, release of data for August 2003.

Sallie Mae is a federally chartered, government-sponsored enterprise that has the majority of its assets in student loans. In 1997, it received authorization to reorganize as a fully private, state-chartered corporation. The following year, the institution became a wholly owned subsidiary of SLM Holding Corporation.

9. Federally guaranteed student loans made by state nonprofit agencies continue to be excluded from the consumer credit statistics because of the lack of frequent and timely data.

10. The Higher Education Act of 1965 authorized the Federal Family Education Loan Program (Pub. L. 89-329) November 8, 1965.

11. The Omnibus Budget Reconciliation Act of 1993 (Pub. L. 103-66), August 10, 1993.

12. Department of Education, Office of Postsecondary Education, Federal Student Loan Programs Databook 1997-2000, www.ed.gov/ finaid/prof/resources/data/ope.html.
1. Debt service and financial obligations ratios, 1980-2003:Q2

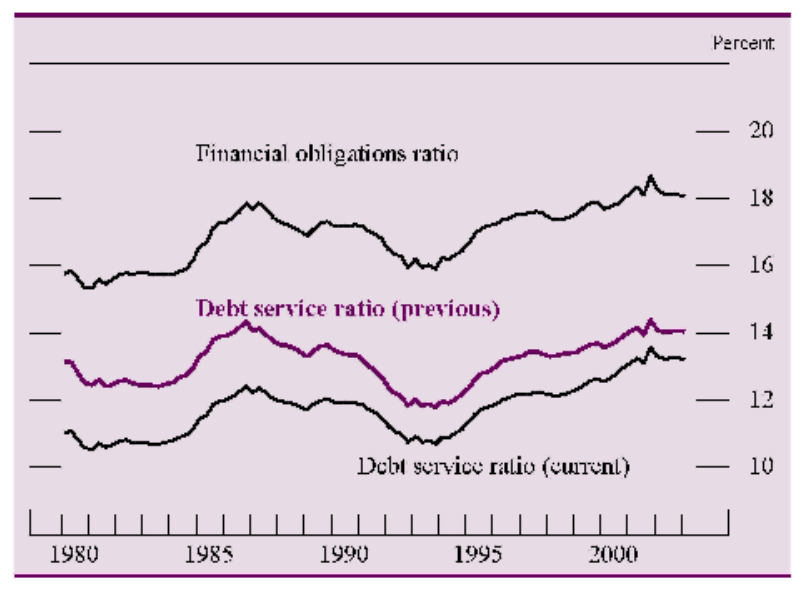

NOTE. Financial obligations include debt service, rent payments, auto lease payments, homeowners' property tax payments, and homeowners' insurance payments.

a private corporation, will be included in consumer loans held by finance companies when statistics from this sector are re-benchmarked in 2005. To avoid such inconsistency in treatment, Sallie Mae's student loans since 1977 were added to the Federal Reserve's G. 19 consumer credit statistics beginning with the October 2003 release. Their inclusion did not materially change the growth rate of consumer credit, but it has raised the level an average of $2 \frac{1}{2}$ percent since 1977.

\section{Revision to the Debt Service Ratio Estimate}

On net, changes to the source data led to a downward revision to the DSR of about $1 \frac{1 / 2}{2}$ percentage points from 1980 through 2002 (chart 1 and top portion of table 3). Revisions to personal loan payments

3. Contributions to the overall revision, $1980-2002$ Percentage points

\begin{tabular}{|c|c|c|c|c|c|}
\hline Component & $1980-89$ & $1990-94$ & $1995-99$ & $2000-02$ & $\begin{array}{l}1980 \\
2002\end{array}$ \\
\hline $\begin{array}{l}\text { New data sources } \\
\text { Student loans }\end{array}$ & -.13 & -.03 & .22 & .50 & .05 \\
\hline Personal loans & -1.44 & -.83 & -1.11 & -1.26 & -1.21 \\
\hline $\begin{array}{l}\mathrm{RV} \text { and marine } \\
\text { loans ....... }\end{array}$ & -.11 & -.28 & -.44 & -.53 & -.27 \\
\hline $\begin{array}{c}\text { Mobile-home } \\
\text { loans ... }\end{array}$ & - & 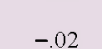 & .09 & .07 & -01 \\
\hline Auto loans ... & -.03 & -.04 & .09 & .29 & .03 \\
\hline Total & -1.80 & -1.20 & -1.14 & -.93 & -1.41 \\
\hline $\begin{array}{l}\text { Broadened debt } \\
\text { senvice burden }\end{array}$ & & & & & \\
\hline Automobile leases & .03 & .21 & .53 & .53 & .33 \\
\hline Rental payments & 3.38 & 3.36 & 3.14 & 2.91 & 3.20 \\
\hline $\begin{array}{l}\text { Property taxes } \\
\text { and insurance }\end{array}$ & 1.70 & 1.71 & 1.66 & 1.57 & 1.66 \\
\hline Total & 5.11 & 5.28 & 5.33 & 5.01 & 5.19 \\
\hline Overall revision & 3.31 & 4.08 & 4.19 & 4.08 & 3.78 \\
\hline
\end{tabular}


accounted for the lion's share of this revision because of the lengthening of our assumptions about remaining maturity on these loans. This revision alone reduced our estimate of the DSR more than 1 percentage point. Reducing the interest rate used to calculate the required debt service on RV and marine loans and lengthening their assumed maturities accounted for most of the remaining revision.

\section{BROADENING THE MEASURE OF HOUSEHOLD LIABILITIES WITH THE FOR}

Because of changes in the mortgage and automobile markets, we created a new measure of household liabilities - the financial obligations ratio (FOR). By including rental payments on primary residences as well as other housing-related expenses, this measure reflects the household sector's movement toward owning (debt financing) and away from renting (lease financing) in the housing market. And by including automobile lease payments, the measure reflects the movement toward leasing in the automobile market. The resulting measure better captures changes in the share of household resources dedicated to recurring fixed expenses. The magnitude of auto lease commitments and the combination of the various housingrelated commitments relative to disposable income appear in chart 2.

\section{Housing Market}

Households have moved from renting toward owning their primary residences. Over the 1990s, the share of households that owned their homes rose from

\section{Financial obligations as a share of disposable} income, 1980-2003:Q2

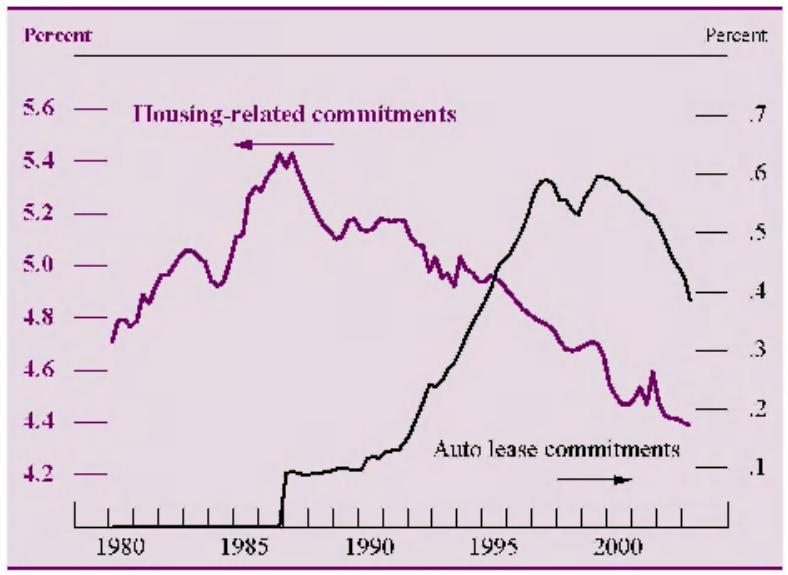

NoTE. Housing-related commitments include rent, property tax, and property insurance payments.
64 percent to about 68 percent. ${ }^{13}$ In the process, these new homeowners likely replaced their rental payments with mortgage debt.

Because of this shift from renting to owning, a measure of household financial obligations that excludes rent on tenant-occupied properties overstates the recent increases in housing-related obligations. To resolve this measurement issue, we added data from 1980 to the present on tenant-occupied, nonfarm rent from the National Income and Product Accounts (NIPA) to the estimates of household debt payments. As a share of after-tax personal income, rent payments rose fairly rapidly between the early and mid-1980s, reaching $3 \%$ percent, and have subsequently fallen to less than 3 percent (bottom portion of table 3). Incorporating rental payments increased the level of the DSR 31/\% percentage points on average between 1980 and 2002 .

To capture all the financial commitments associated with homeownership, a measure of household financial obligations should also include expenditures, such as property taxes and homeowners' insurance, that must be paid but are not part of mortgage debt. From 1980 through 1994, aggregate property taxes paid by households as a share of total disposable personal income hovered around $1 \% 2$ percent. Since that time, property taxes have edged down to an estimated $1 \frac{1 / 3}{3}$ percent of income. Homeowners' insurance payments as a percentage of disposable personal income are quite small, averaging less than 1,4 percent over the past two decades. Taken together, property taxes and homeowners' insurance payments account for $1 \%$ percentage points of the difference between the FOR and the DSR from 1980 through 2002

\section{Auto Market}

In contrast to the housing market, in the automobile market, households have shifted somewhat from owning their vehicles and incurring debt to leasing (renting) their vehicles. In 1992, 21,2 percent of households leased a vehicle. By 2001, this figure had risen to $5 \% / 4$ percent. $^{14}$ Because of this shift, a measure of financial obligations that excludes automobile

13. U.S. Census Bureau, "Housing Vacancies and Homeownership Historical Tables," table 14, http://www.census.gov/hhes/www/ housing/hvs/historic/histt14.html.

14. See Ana M. Aizcorbe, Martha Starr, and James T. Hickman, "The Replacement Demand for Motor Vehicles: Evidence from the Survey of Consumer Finances," Board of Governors Finance and Economics Discussion Series 2003-44, www.federalreserve.gov/pubs/ feds/. 
leases understates increases in consumers' required automobile finance payments. 'Accordingly, we added automobile lease expenditures from the NIPA to our estimate of household debt payments. Lease payments account for roughly 1,3 percentage point of the difference between the FOR and the DSR.

\section{Comparison of the DSR and the FOR}

Broadening the measure of household liabilities had a larger effect on the level of the DSR than on its contour over time. Mainly because of the addition of rental payments on tenant-occupied housing, the new FOR measure is about 51,4 percentage points higher on average than the revised DSR measure between 1980 and 2002 (chart 1). The FOR has varied between 15 percent and 19 percent since 1980 , with a high in the fourth quarter of 2001 (chart 3).

The growth in debt outstanding explains much of the movement in this measure, although changes in interest rates and maturities contribute as well. In the mid-1980s, rapid growth in the major categories of household debt-mortgages, credit card debt, and automobile loans-led to a rise of 2 percentage points in the FOR. During the recession in the early 1990s, nonrevolving consumer debt contracted, mortgage growth was sluggish, and the FOR dropped 1\% percentage points. In the mid-1990s and again around the turn of the century, rapid debt growth pushed the FOR higher.

\section{The financial obligations ratio, 1980-2003:Q2}

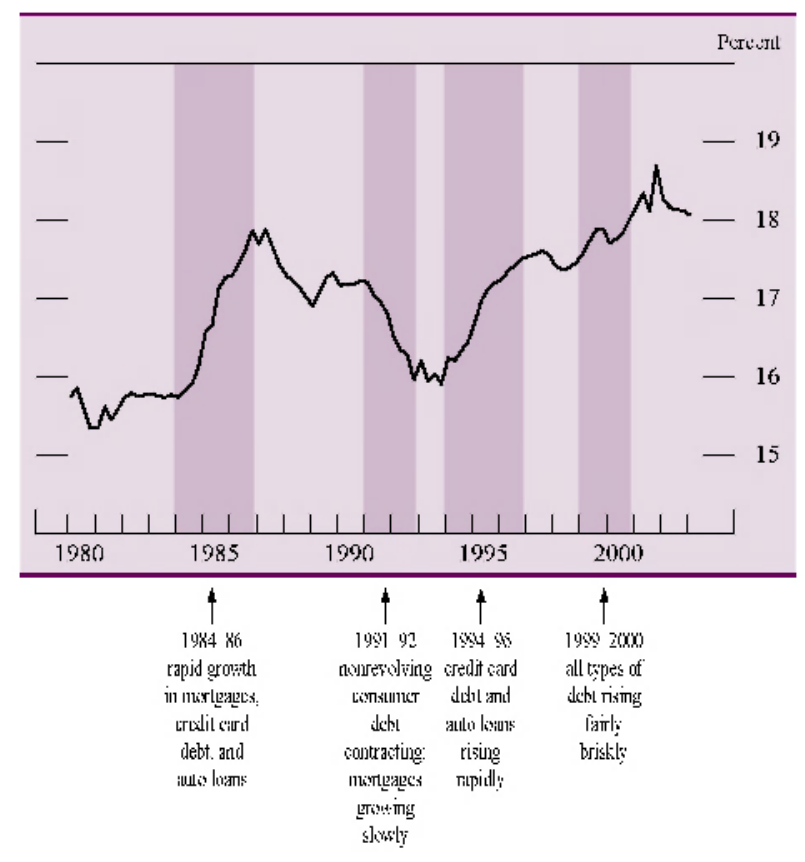

\section{DEBT SERVICE AND FINANCIAL OBLIGATIONS BY HOMEOWNERSHIP STATUS}

Record low interest rates and rising house prices over the past few years have prompted millions of homeowners to refinance their mortgages and to tap into their home equity. ${ }^{15}$ The net effect of these refinancings on the outstanding debt of homeowners is ambiguous. If homeowners reduce their mortgage payments through refinancing or if they pay off higher-cost consumer debt with the proceeds of a cash-out refinancing (that is, tap into their equity and take out cash), homeowner debt service will decrease. By lowering required monthly payments, this balance sheet restructuring may make homeowners' consumption less vulnerable to income declines. However, if homeowners use the proceeds of a cash-out refinancing to finance new consumption, homeowner debt service may increase. For these reasons, it is useful to separate financial obligations of homeowners from those of renters. The changes in the ratio of homeowners' financial obligations to their incomes may summarize the net effect of the refinancing boom on the financial situations of homeowners.

Separating homeowner and renter financial obligations also allows the creation of a renter financial obligations ratio. In general, renters have less income than do homeowners and are more likely to have trouble repaying their financial obligations. In 2001, the median income of renters was $\$ 24,700$; the median income of homeowners was $\$ 52,100$. In the same year, 14 percent of renters and only 4 percent of homeowners said that they had been delinquent sixty days or more on a loan in the past year. ${ }^{16}$ Thus, a separate financial obligations ratio for renters may indicate how the debt obligations of households with less income and less wealth have changed over time.

However, splitting homeowners' and renters' financial obligations involves complications in terms of both computation and interpretation. First, the aggregate data series used in calculating the FOR are not, in general, available separately for homeowners and renters. Thus, the income and obligation series for each group must be estimated using householdlevel survey data. The methods used to estimate these series are described later in this article. Second, the rise in the rate of homeownership opens the possibil-

15. See Glenn Canner, Karen Dynan, and Wayne Passmore, "Mortgage Refinancing in 2001 and Early 2002," Federal Reserve Bulletin, vol. 88 (December 2002), pp. 469-81, for more discussion of the recent refinancing boom.

16. See Aizcorbe, Kennickell, and Moore, "Recent Changes in U.S. Family Finances," tables 1 and 14. 
4. Distribution of the debt of homeowners and renters, by loan type, 1990-20021

Percent

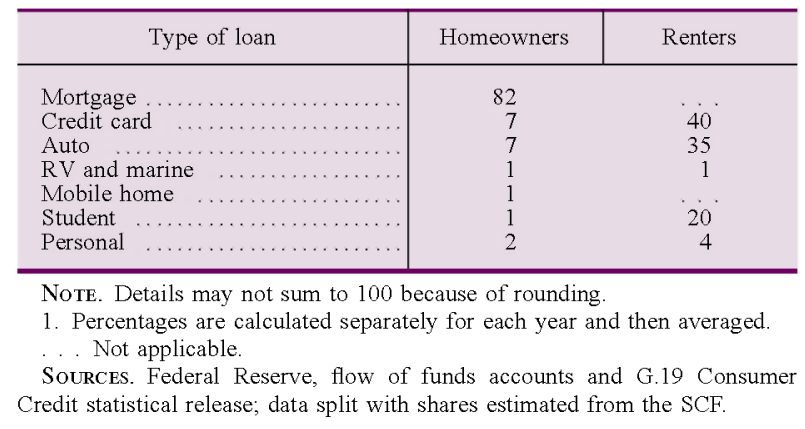

ity that the characteristics of homeowners as a group may have changed over time. Therefore, changes in the homeowner FOR may reflect changes in the characteristics of new homeowners rather than changes in the financial commitments of existing homeowners. A rough estimate of the extent of this effect, presented at the end of the article, suggests that up to half the rise in the homeowner FOR over the 1990s may be due to the increase in homeownership.

\section{Estimating the Financial Obligations of Homeowners and Renters}

The debt of renters and owners is distributed differently across loan types. Mortgages are the dominant component of the debt of homeowners, whereas credit card, auto, and student loans are the major components of the debt of renters (table 4). As a result, changes in mortgage interest rates will affect the FOR only of homeowners, whereas changes in consumer loan interest rates will disproportionately affect the FOR of renters.

To split aggregate debt service, for each type of loan we estimate the share of debt service accruing to homeowners and renters. These shares, which are estimated from the SCF, are then applied to each loan type's aggregate debt service. Auto lease payments are also split based on estimates from the SCF, whereas homeowners' insurance and property taxes are assigned entirely to homeowners and rent payments are assigned entirely to renters.

\section{Estimating the Income of Homeowners and Renters}

Conceptually, estimating the income of homeowners and renters is similar to estimating their debt pay- ments. Using survey data, we estimate the shares of various types of income accruing to homeowners and renters. We then use these shares to split the aggregate NIPA income data between homeowners and renters.

In practice, estimating the income of homeowners and renters is more complicated than estimating their debt payments for two reasons. First, the definition of income in NIPA data is different from that in survey data. The NIPA definition includes components such as the rental value of owner-occupied housing, employer contributions to private pension funds, and the value of Medicare and Medicaid entitlements, which are generally excluded from survey-based definitions. Second, some sources of survey data may undercount high-income households, whose income is a significant fraction of aggregate income. Moreover, in some surveys the true incomes of these high-income households are replaced with lower figures in an attempt to maintain the households' confidentiality. Because an overwhelming percentage of high-income households are homeowners, excluding their income may induce a downward bias in the estimate of the homeowner share of income.

To mitigate the difficulties raised by differences in income definitions, each component of NIPA income is matched to its closest equivalent in survey data (table 5). This method assumes only that the same share of income accrues to renters and homeowners within each subcategory for the NIPA and survey data, rather than within the NIPA and survey data as a whole. For components in which the income of highincome households plays a significant role-wage, self-employment, rental, dividend, and interest income - the homeowner/renter split is based on the Survey of Consumer Finances, which oversamples these households specifically. For other income sources, the split is based on the March supplement to the Current Population Survey (CPS), which is conducted more frequently than is the SCF and is

5. NIPA income subcategories and survey data equivalents

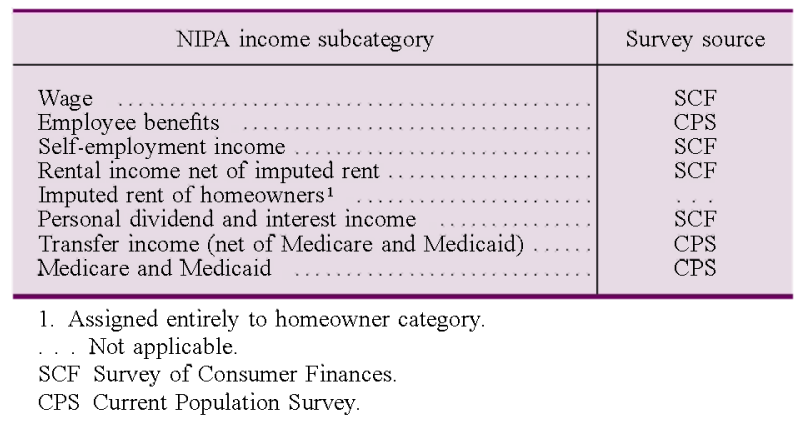




\section{Microdata Sets Used to Calculate the Homeowner and Renter FORs}

The Federal Reserve Board conducts the Survey of Consumer Finances (SCF) every three years. The survey is designed to provide comprehensive data on the wealth (both the assets and the liabilities) of American households. The SCF oversamples high-income households because these households hold a disproportionate share of the nation's wealth. Weighting is used in estimation to give each survey case its approximate representation in the full population of households. Survey waves are currently available for 1983, 1986, 1989, 1992, 1995, 1998, and 2001. The 2001 survey data were released publicly approximately fifteen months after the completion of the interviews and contained data from interviews with 4,442 households.

The Bureau of the Census conducts the Current Population Survey (CPS) monthly and asks detailed questions about income annually in its March supplement. The survey is designed to provide information on the labor force characteristics of the U.S. population. The CPS web site has March supplement data from 1992 onward, and the Unicon Corporation's "CPS Utilities" provides this data from 1962 onward. The data for the 2002 March supplement were released approximately six months after the completion of the interviews and contained data from approximately 78,000 households.

based on a larger number of households. (See the box for more information on these surveys.) Besides being more frequent, the CPS also asks more detailed questions about the many possible sources of transfer income, such as food stamps and Temporary Assistance to Needy Families, and thereby yields a potentially better measure for this category than does the SCF. Federal and state tax shares are estimated with the internal version of the SCF and the National Bureau of Economic Research's TAXSIM model. ${ }^{17}$

The income of homeowners and renters is distributed differently across the sources of income. Dividends, interest, and self-employment income represent 28 percent of the income of homeowners but only 8 percent of the income of renters (table 6). Transfer income and Medicaid make up only 9 percent of the income of homeowners but 23 percent of the income of renters. Thus, changes in the stock and bond markets will affect homeowners disproportionately, and changes in the rules governing transfer programs will influence primarily renters.

17. State identifiers are not released on the public version of the SCF. For more information on the TAXSIM model, see www.nber.org/ $\sim$ taxsim.
6. Distribution of homeowner and renter income across sources, 2001

Percent

\begin{tabular}{|c|c|c|}
\hline Income source & Homeowners & Renters \\
\hline Wages & 53 & 63 \\
\hline $\begin{array}{l}\text { Dividends, interest, and } \\
\text { self-employment income }\end{array}$ & 28 & 8 \\
\hline Transfers and Medicaid .... & 9 & 23 \\
\hline Employee benefits and Medicare & 9 & 7 \\
\hline
\end{tabular}

NotE. Details do not sum to 100 because rental income and imputed rent of homeowners are excluded from the table.

SoURCE. NIPA income data split with shares estimated from the CPS and $\mathrm{SCF}$.

\section{The Financial Obligations Ratios for Homeowners and Renters}

The financial obligations ratio for renters is substantially higher than that for homeowners (chart 4). The renter ratio is higher than the owner ratio because renters as a group spend a greater share of income on housing and on consumer debt payments. Renters as a group spent 17 percent of their total after-tax income on rent payments, whereas homeowners as a group spent only 7.7 percent of their total after-tax income on mortgage payments, homeowners' insurance, and property taxes. Renters also spent 5 percentage points more of their income than homeowners did on consumer debt payments.

The financial obligations ratios for homeowners and renters also have different contours over time. The homeowner FOR moved largely in lockstep with the aggregate measure over the 1980s and 1990s, whereas the renter FOR accelerated over the 1990s. Over the 1992-2002 period, the homeowner ratio rose 2.0 percentage points, and the renter ratio rose 6.8 percentage points.

4. Financial obligations ratios for homeowners and renters, 1980-2003:Q2

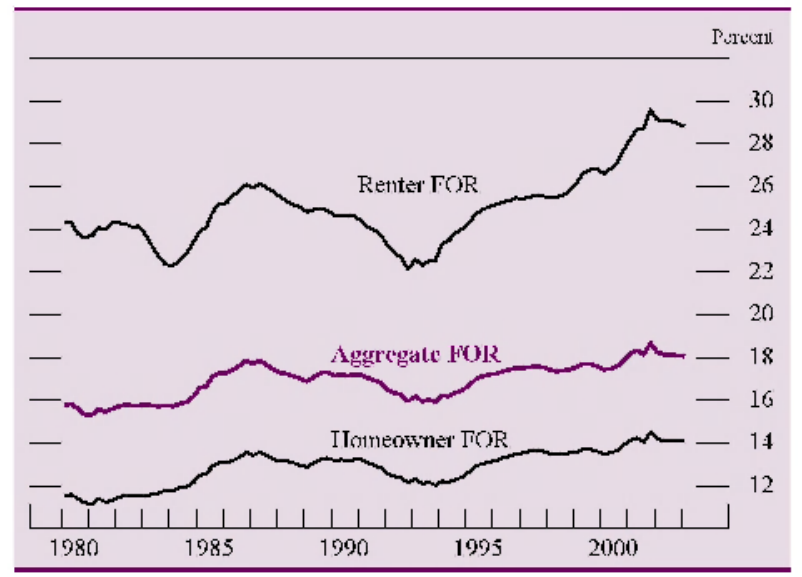


The renter ratio has risen more sharply than has the homeowner ratio since the early 1990 s because renters experienced less growth in income than homeowners did. From the fourth quarter of 1992 to the fourth quarter of 2001 , which is the most recent peak of the FOR series, the income of renters rose 22 percent, and the income of homeowners rose 60 percent. In addition, for the first part of this period-roughly from 1993 to 1995 - renter debt payments rose at a faster rate than homeowner debt payments did.

\section{The Rise in Homeownership and the Homeowner Financial Obligations Ratio}

The increase in homeownership over the 1990s appeared to stem in part from changes in the mortgage market, as the mortgage industry became more sophisticated at developing products for borrowers with impaired credit or with limited funds for a down payment. If these new homeowners, who would have been renters in the past, have high debt levels relative to their incomes, the homeowner FOR will increase. However, this increase will not signal that existing homeowners have taken on more debt; it will reflect simply the changing composition of the homeowner pool.

The effect of this rise in homeownership on the homeowner FOR cannot be precisely estimated because we have no way of identifying current homeowners who would have been renters under the prevailing lending standards of the past. However, recent research by Federal Reserve staff suggests that the increase in homeownership over the 1990s was concentrated among households with limited funds for a down payment. ${ }^{18}$ As a rough attempt to quantify the magnitude of this new-homeowner effect, we isolated the new homeowners in the 1995, 1998, and 2001 Surveys of Consumer Finances with the largest mortgage loans relative to their house values. For each of these waves of the SCF, we chose enough of these households so that, when they were removed from the homeowner group, the homeownership rate would be reduced to its 1992 value.

Removing these new homeowners from the homeowner group subtracts about half the growth in the homeowner FOR over the 1990s (chart 5). This change may be an upper bound on the magnitude of the effect because we removed from the homeowner

18. See Irina Barakova, Raphael Bostic, Paul Calem, and Susan Wachter, "Does Credit Quality Matter for Homeownership?" unpublished paper, Federal Reserve Board, January 6, 2003.
5. Effect of rise in homeownership on homeowner financial obligations ratio, 1989-2003:Q2

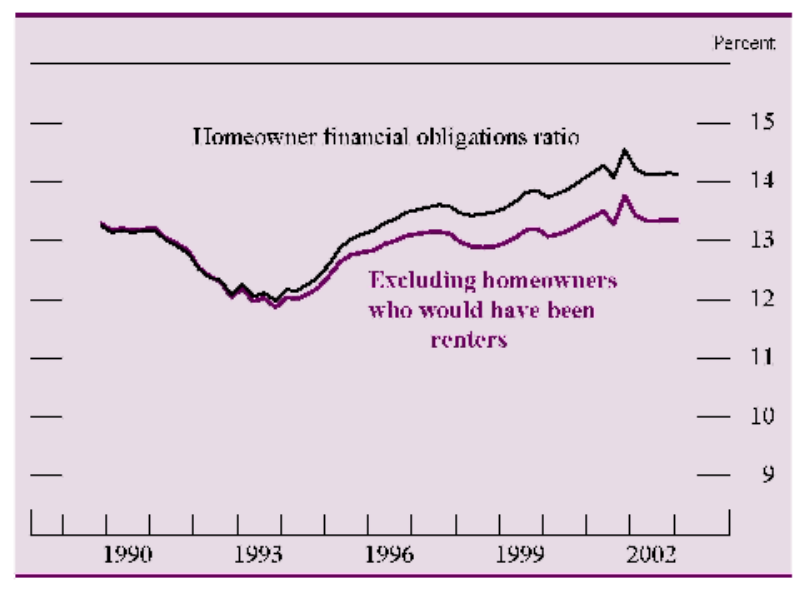

pool some of the households with the highest levels of debt. Indeed, excluding these households decreases the debt service payments of homeowners 11 percent, whereas their income decreases only 4 percent. This estimate suggests that the rise in the homeowner FOR over the 1990s reflects an increase in both the indebtedness of homeowners and in the rate of homeownership.

\section{SUMMARY}

Recent changes in financial markets have necessitated changes to the structure and the methodology of the debt service ratio statistics. The new household financial obligations ratio, introduced in this article, adds rent, auto lease payments, and other recurring obligations to the household debt service ratio. Both the new household FOR and the revised household DSR incorporate an expanded measure of consumer credit and revised estimates of loan maturities and interest rates. The new FORs for homeowners and renters provide separate estimates of the indebtedness of these groups relative to their respective incomes.

On net, these changes in methodology have raised the level of the DSR but have not substantively changed its trajectory over time. As was true before the revision, the DSR in 2002 was similar to the peak level reached in the 1980s. The homeowner FOR, like the aggregate FOR, increased gradually during the $1990 \mathrm{~s}$, whereas the renter FOR rose more steeply. However, both the homeowner and the renter FORs have remained largely unchanged over recent quarters. Homeowners appear to have managed their liaabilities through the recent period of economic weakness by rebalancing their portfolios toward lower-cost mortgage debt. 


\section{APPENDIX: DEBT SERVICE CALCULATTON.}

To calculate household debt service, the following formula for principal and interest payments is applied for each type of installment loan:

$$
d s_{i, t}=\frac{r_{i, l} d_{i, t}}{1-\left(1+r_{i, t}\right)^{-m_{i, t}}}
$$

where $d s_{i, t}$ is the debt service, $d_{i, t}$ is the stock of debt, $r_{i, t}$ is the average interest rate on that stock, and $m_{l, t}$ is the remaining maturity for loan type $i$ at time $t$.

\section{Mortgage Debt Service}

To calculate the mortgage debt service, we use mortgage debt as published by the Federal Reserve in its flow of funds accounts and the effective interest rate on outstanding mortgage debt as calculated by the Bureau of Economic Analysis based on a perpetual inventory of mortgage loans. The remaining maturity equals the weighted average maturity on mortgage loans in pools securitized by Fannie Mae, Freddie Mac, and other lenders.

\section{Nonrevolving Consumer Debt Service}

We use nonrevolving consumer debt as published by the Federal Reserve in its G.19 Consumer Credit statistical release. In general, this debt is split into loans for new automobiles, loans for used automobiles, student loans, mobile-home loans, RV and marine loans, and personal loans by applying shares of these loans estimated from survey data.

The average interest rate on the stock of loans for new automobiles is estimated by applying a distribu- tion of loans by vintage, which was calculated from the SCF, to a quarterly interest rate series for new auto loans newly originated by commercial banks and finance companies. Using the same method, we estimate the rate on the stock of used automobiles with a quarterly interest rate on used auto loans newly originated by finance companies. The average interest rate on the stock of student loans, mobilehome loans, RV and marine loans, and personal loans is a backward moving average of the rate on new loans for that type of debt (or a proxy for that interest rate).

Average remaining maturities on the stock of new and used automobile loans are estimated with the same procedure as that for the interest rates. We assume that remaining maturities on other types of loans are fixed over time.

\section{Revolving Consumer Debt Service}

We use revolving consumer debt as published by the Federal Reserve in its G.19 Consumer Credit statistical release. We assume that revolving debt is composed of credit card debt only, although other types of revolving debt are likely included. ${ }^{10}$ The assumed minimum required payment rate is 2,2 percent of the balance per month, based on the January 1999 Senior Loan Officer Opinion Survey, in which most banks indicated that required monthly minimum payments on credit cards ranged between 2 percent and 3 percent and had not changed substantially over the previous decade.

19. The largest type of revolving debt outside credit card debt is likely the overdraft protection provided on many checking accounts. 